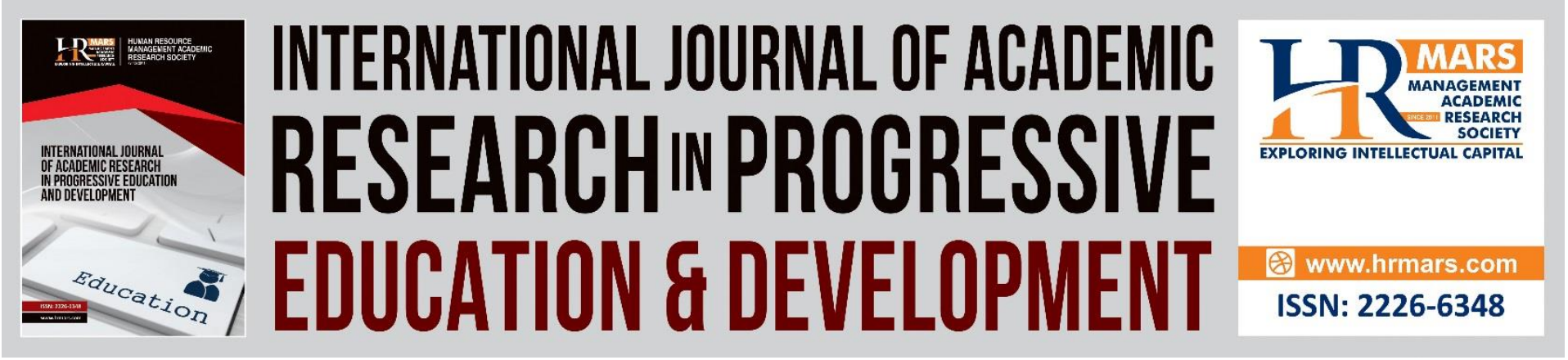

\title{
Students' Perceptions of Online Learning During Pandemic Outbreak: A Case Study of Electrical Engineering Students
}

Nur lqtiyani Ilham, Arni Munira Markom, Wan Suhaifiza Wan Ibrahim

To Link this Article: http://dx.doi.org/10.6007/IJARPED/v10-i3/11365

DOI:10.6007/IJARPED/v10-i3/11365

Received: 08 July 2021, Revised: 30 July 2021, Accepted: 20 August 2021

Published Online: 29 September 2021

In-Text Citation: (Ilham et al., 2021)

To Cite this Article: Ilham, N. I., Markom, A. M., \& Ibrahim, W. S. W. (2021). Students' Perceptions of Online Learning During Pandemic Outbreak: A Case Study of Electrical Engineering Students. International Journal of Academic Research in Progressive Education and Development, 10(3), 1266-1274.

Copyright: (C) 2021 The Author(s)

Published by Human Resource Management Academic Research Society (www.hrmars.com)

This article is published under the Creative Commons Attribution (CC BY 4.0) license. Anyone may reproduce, distribute, translate and create derivative works of this article (for both commercial and non-commercial purposes), subject to full attribution to the original publication and authors. The full terms of this license may be seen

at: http://creativecommons.org/licences/by/4.0/legalcode

Vol. 10(3) 2021, Pg. 1266 - 1274

http://hrmars.com/index.php/pages/detail/IJARPED

JOURNAL HOMEPAGE

Full Terms \& Conditions of access and use can be found at http://hrmars.com/index.php/pages/detail/publication-ethics 


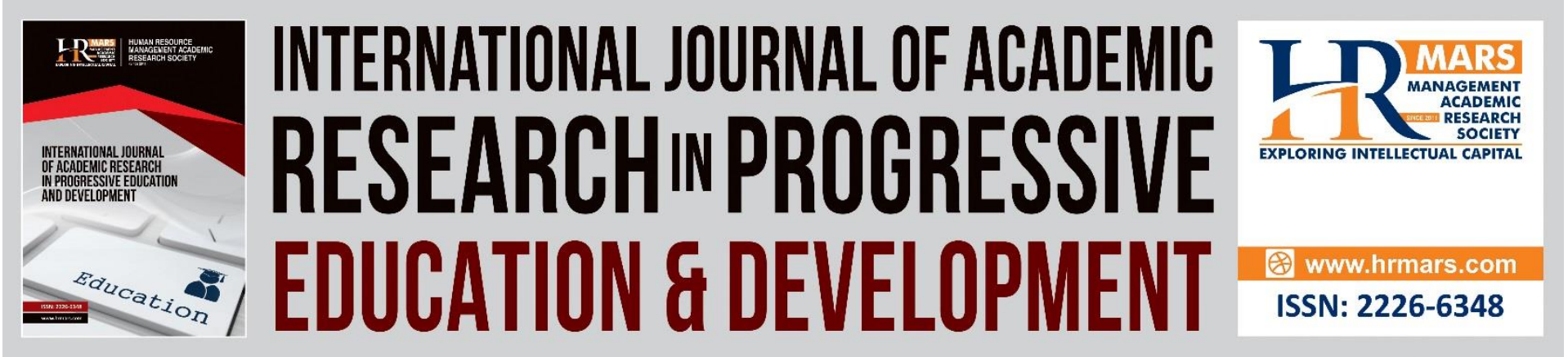

\title{
Students' Perceptions of Online Learning During Pandemic Outbreak: A Case Study of Electrical Engineering Students
}

\author{
Nur Iqtiyani Ilham, Arni Munira Markom, Wan Suhaifiza Wan \\ Ibrahim \\ School of Electrical Engineering, College of Engineering, Universiti Teknologi MARA, 81750 \\ Masai, Johor, Malaysia \\ Email: iqtiyani9089@uitm.edu.my,wsuhaifiza@uitm.edu.my
}

\begin{abstract}
The outbreak of COVID-19 pandemic had reformed the old-millennia teaching and learning method worldwide. The new norm of academic activities has now been dominant by online learning platform. However, accessing the effectiveness of the online learning method, especially for electrical engineering students, is still not clearly understood. As this course required the integration of theoretical, mathematical and laboratory works, hence the online learning method can be disputed without a proper planning. The technical constraints such as learning infrastructures, conducive space, and internet connection availability can pose to severe challenges in this new norm. Without proactive action taken by the university and lecturers, these problems will remain unsolved. Therefore, this study aims to analyze students' perception of online learning during a visit of COVID-19. Two (2) stages of survey such as entry and exit had been distributed to electrical engineering students who took the electrical machines course in their fourth semester. From the results obtained, students opined that online teaching and learning were much effective when the lecturers provide adequate learning materials (i.e., notes, video, assessments and recording classes) in synchronized and asynchronized methods. These methods assisted students to study and do revision at a flexible time following their own pace. In general, the students were not having any issues on the lecturers' professionalism in delivering lectures, preparing materials and assessments. From a bright perspective, rapid transformation to online learning had turned the students' competence in handling digitalization technology. Ultimately, the insight obtained from the survey analyzes can assist the university in designing the curriculum to adapt the new normal in teaching and learning.
\end{abstract}

Keywords: Online Distance Learning, Electrical Engineering, University, Students' Perception, Entry Survey, Exit Survey 


\section{Introduction}

Since the Covid-19 outbreak, the pandemic has severely impacted humans' global activities. The virus had spread rapidly worldwide, thus forcing many governments to close education institution to protect their students from viral exposure. According to the United Nations Educational, Scientific and Cultural Organization (UNESCO), by April 2020, about $73.8 \%$ of students from 186 countries had affected their normal physical learning session with the closure of education institutions (UNESCO, 2020). Similarly, the Ministry of Higher Education (MoHE) in Malaysia had issued a circular note to all universities to temporarily close at the indefinite period due to COVID-19 viral (Selvanathan et al., 2020). Consequently, students and all lecturers had to undergo an online distance learning (ODL) session.

Despite the closure of many educational institutions, the teaching and learning activities should not stop since the academic calendar has already been stipulated for the syllabus to be completed. This type of performance measure might cause some difficulties for students and lecturers to immediately transform the conventional lecture-based approaches (Markom et al., 2021). However, looking at the bright side on a dark cloud, the pandemic had made the education sector more accessible and interactive with the combination of digital learning and technologies (Asgari et al., 2021). From the perspective of educators, they should quickly trigger the creative ways to conduct online classes using any suitable platform such as Microsoft Teams (MT), Zoom, Google Classroom etc (Muthuprasad et al., 2021). The platform used should keep the frequent interaction and students participation since these elements are crucial to the success of online learning (Huggett, 2014).

A careful planning should be deployed to mitigate the impact of ODL during the pandemic, especially to the engineering students, since this subject requires many theoretical and mathematical contents syllabus. Apart from the university's ideal online teaching courses, the students' perception must be considered in the evaluation of ODL effectiveness (Khan \& Abid, 2021). This is because students can easily get the psychological stress at their age due to movement control order (MCO) and social distancing enforced (Abid \& Khan, 2018). Furthermore, students also need to adapt quickly to the new environment, which is totally based on computer (Sanchez-Gordon \& Luján-Mora, 2014).

Withal, by taking electrical engineering students from one of the educational institutions in Malaysia as a sample, this paper aims to observe the students' perception and experiences through ODL method during the COVID-19 pandemic outbreak. This study is essential as it will assist Malaysian MoHE in online learning sessions by providing insight into students' feedback.

\section{a. Learning Outcomes of the Course Design}

The course has been designed properly to suit the requirement of a diploma for electrical engineering according to Malaysian Qualifications Agency (MQA) accreditation (Malaysian Qualifications Agency, 2021). At the end of a course syllabus, students are expected to acquire adequate knowledge about a principle of three-phase system, a single-phase transformer, induction motor, synchronous machines, DC machines and special machines. The students should be able to analyze, assess, correlate and explain the principle application of an electrical machines mentioned above. The element of cognitive, psychomotor and affective 
DEVELOPMENT

Vol. 10, No. 3, 2021, E-ISSN: 2226-6348 @ 2021 HRMARS

have been used as a course learning outcomes assessment in teaching and learning activities such as tests, assignments, workgroups and presentations.

\section{b. Organisation of the Course Contents}

The best practise applied for this course is by ensuring students to lecturer ratio is $25: 1$ for each class. Therefore, for this course, there are four (4) groups that have been allotted and been thought by three (3) lecturers as illustrated in Figure 1 . The accumulative $100 \%$ is considered from total 91 students participating in this case study. The group consists of J4EE1124A, J4EE1124B, J4EE1124C and J4EE1124D. The J4 term represent the Pasir Gudang campus in Johor, EE is an electrical engineering, 112 indicate that students for these groups are majoring in power engineering, 4 means students' current semester ( $4^{\text {th }}$ semester) while lastly, A, B, C and D are meant for students' groups.

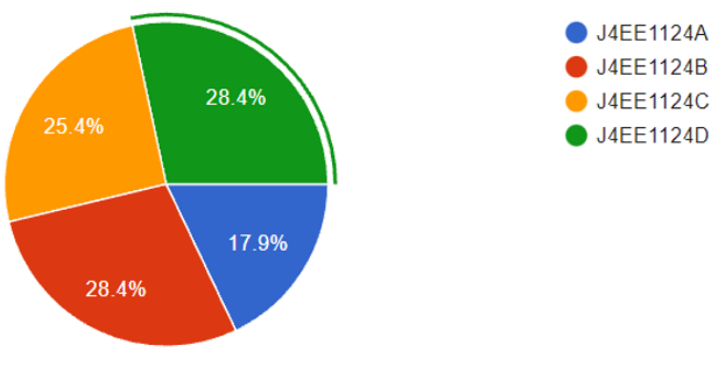

Figure 1: Students' allocation according to classes

As shown in Figure 2, the syllabus contents for this course consist of six (6) chapters that to be covered throughout the 14 weeks of lectures and tutorials. This course is structurally aligned with the program's educational objectives to support an electrical engineer who can apply the knowledge while demonstrating value, attitudes, social skills, and communicating effectively.
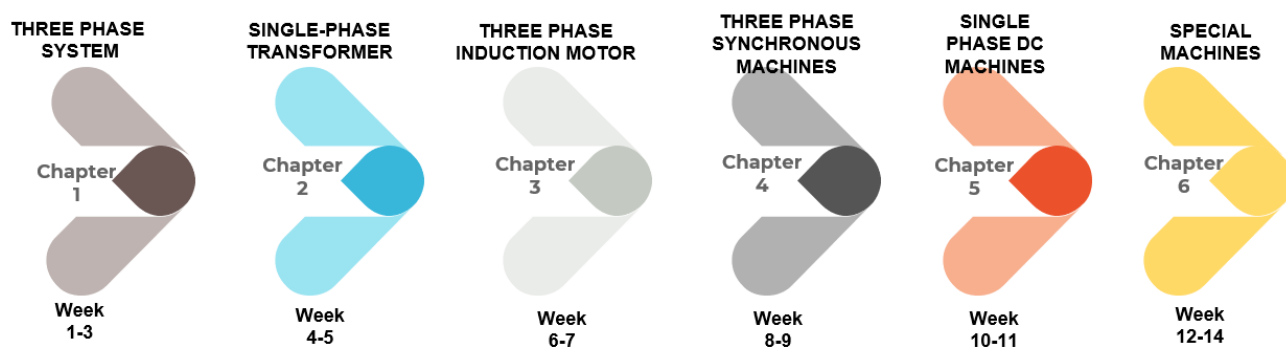

Figure 2: Course syllabus and timeline

\section{c. ODL Teaching Strategies}

Previously, the normal practice to access student's performance in this subject was through final exams and assignments with both carries $60 \%$ and $40 \%$ respectively. However, due to the restricted movement regulations of COVID-19, the final physical examination could not be carried out. Therefore, the university had instructed the lecturer in charge of this subject to produce a new course assessment plan (CAP) compatible with the current situation and constraints. Hereof, the new CAP has been stipulated that these two (2) tests and two (2) assignments will be conducted as a substitute for the normal practice assessment. Test 1 was conducted in the $8^{\text {th }}$ lecture week, while test 2 is in the $14^{\text {th }}$ week. Table 1 shows the 
comparison for course assessment for this subject normal face-to-face (f2f) and during ODL. The teaching methodologies for this subject remain with lectures and tutorials using the formal online platform i.e., Microsoft Team (MT). The MT is a robust online platform capable of delivering productive online streaming classes, attractive file structures, online submission for assignments or reports with participant records, date and time tracing, and well-organized activity feeds.

Table 1: Students' assessment for normal (f2f) and ODL scenarios.

\begin{tabular}{|l|l|l|}
\hline Assessment & Normal (f2f) & ODL \\
\hline Assignments & $10 \%$ & $10 \%$ \\
\hline Tests & $30 \%$ & $90 \%$ \\
\hline Final & $60 \%$ & N/A \\
\hline
\end{tabular}

WhatsApp Messenger has been used widely globally among students to share information, files, photos etc. It can be easily assessed anywhere, either in rural or urban areas, ideal for communication. The same messenger has been used for this course as the informal platform to disseminate all the information regarding the course timetable or any inquiries raised between lecturers and students.

\section{Methodology}

\section{A. Sample}

In this analysis, a total of 91 electrical engineering students have been taken as respondents. Those students are majoring in Electrical Power Engineering and are currently at their fourth semester of study from five (5) semesters. The gender participation for this analysis consists of $59 \%$ male and $41 \%$ female. The subject named Electrical Machines, consisting of six (6) chapters dominant by 3-phase machines and transformers, has been chosen for this case study. Since the pandemic COVID-19 strike Malaysia in early of 2020, respondents are the first batch that had gone through the online distance learning (ODL) method. Since the students and lecturers had subscribed to the Microsoft account, the platform is therefore used for teaching and learning during the ODL by using with MT.

\section{B. Instruments}

Two (2) stages of surveys i.e., 1) entry survey and 2) exit survey, have been performed to evaluate the students' feedback on the lecturers and the subject during the ODL session. The questions were deliberately designed with the assist of previous literature surveys and discussions with the students. Both mentioned surveys have been conducted using the established Google form tool, while a Microsoft Excel spreadsheet has been used to analyze the collected results. The entry survey mainly focuses on the students learning devices availability, the internet speed performance and students' preliminaries knowledge on the subject. On the other hand, exit survey assessed the students' impression about the course, lecturer professionalism and, teaching and learning delivery activities. 
DEVELOPMENT

Vol. 10, No. 3, 2021, E-ISSN: 2226-6348 @ 2021 HRMARS

\section{c. Research Procedures}

During the first week of the lectures, the students have been given the introduction to the ODL lesson plan, materials, and platform to be used in this course. On the first meet, the lecturers had distributed the entry survey to obtain an early observation of the students' readiness and limitations. The first assignment was handed out to students in week 6 for the induction motor's chapter, while the second assignment in week 13 covered chapter $4-6$. Week 8 and week 14 are allocated for Test 1 and Test 2, covering chapters $1-3$ and $4-6$, respectively. The exit survey on student feedback was handed out on week 14 to assess their perception throughout the ODL session.

\section{Analysis and Results}

As mentioned earlier, two (2) surveys (i.e., entry and exit) have been conducted. Figure 3 show the result obtained in measuring students' infrastructures readiness and availability during the entry survey. It indicates that most of the students have a conducive space and that their equipment or device used for the ODL session is well functioning. This result has been supported by the result on internet line speed having students as presented in Figure 3. Internet performance and speed have been categorized in three (3) scale types: excellent, medium, and poor. It was observed that $18 \%$ of students responded that they have a poor internet connection while most of them are experiencing an excellent connection as depicted in Figure 4.

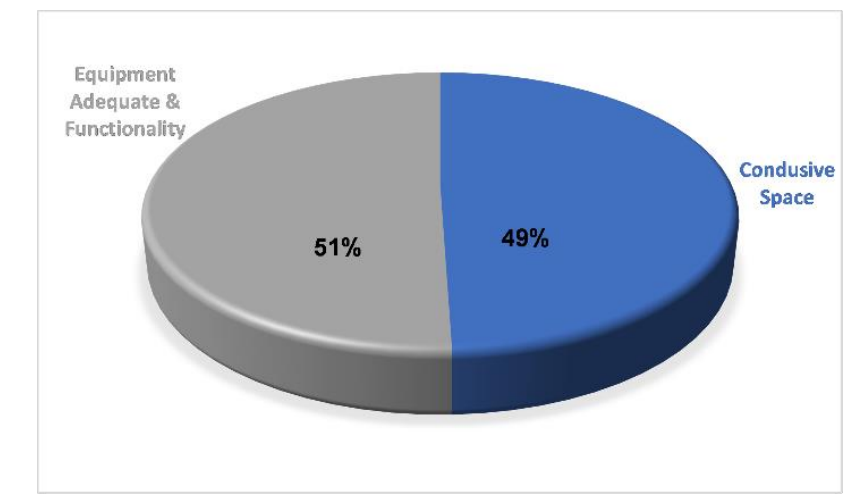

Figure 3: Students learning infrastructure readiness

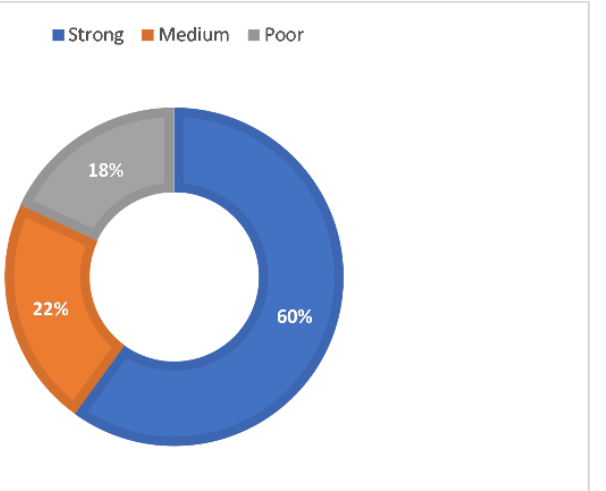

Figure 4: Students' internet speed performances

After 14 weeks of lectures and tutorials, the students will evaluate the subject and lecturers' performance based on the implemented teaching and learning method. The overall impression measured was the element of the students' level of knowledge, the subject related to the electrical course, the assessment method used and the level of self-confidence 
DEVELOPMENT

Vol. 10, No. 3, 2021, E-ISSN: 2226-6348 @ 2021 HRMARS

(see Figure 5). The assessment ranking level indicates 1 as 'strongly disagree', and 5 represents 'strongly agree' for each survey statement.

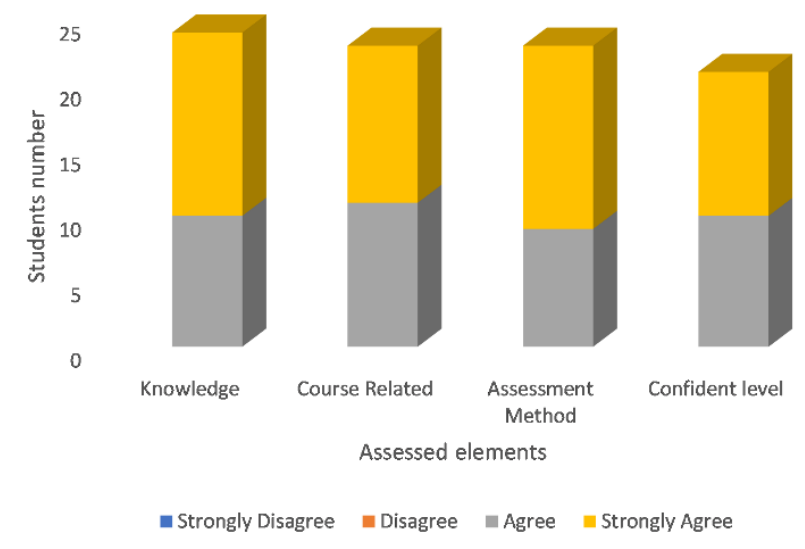

Figure 5: Overall students' perception

Regarding the professionalism of the lecturers in conducting the teaching during the ODL session, Figure 6 shows the elements surveyed. With the stipulated four (4) hours of lectures and tutorials session for each week, the students had given significant remarks on the lecturers' commitments in this subject. Figure 6 below shows the elements evaluated on lecturers' professionalism based on students' observation. Obviously, discredit on lecturers' performances is none of the issues that can be raised.

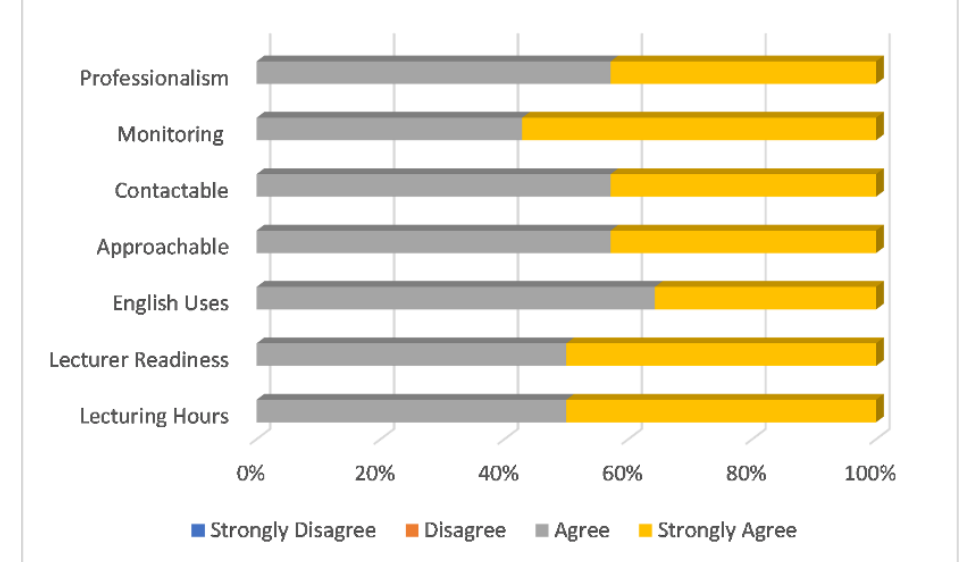

Figure 6: Students' feedback based on lecturer professionalism

By switching the normal to virtual classes, it will literally contribute to various unexpected challenges to university students. The students tend to detach with the classes due to several factors such as the internet connection, the infrastructures readiness and the activities conducted during the teaching and learning. Therefore, based on the CAP developed, students and lecturers' engagement, the overall teaching and learning assessment has been illustrated in Figure 7. The survey included these elements to ensure that any challenges suppressed during the ODL session can be analyzed and recommended for future improvement. On average, most of the students agreed that the teaching and learning activities during ODL session are attractive for this course considering the lecturers' feedback, assistance, environment, course contents, assessment method, and students' participation. 


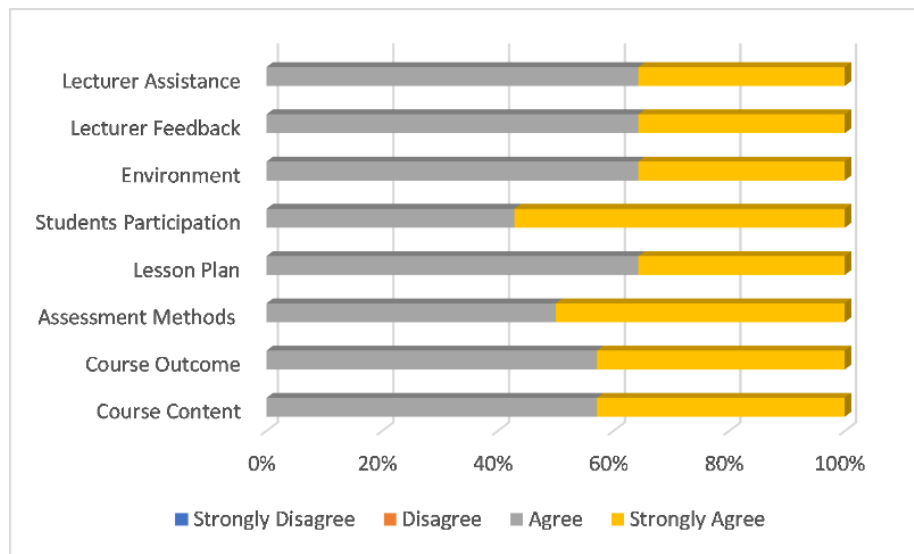

Figure 7: Teaching and learning activities assessment

\section{Discussion}

With the result presented, overall, the students were generally sufficiently willing to use ODL learning infrastructures. Therefore, student's participation is observed to be active and interactive throughout this online session. The used of laptop and smartphones are already common for students to even before the ODL session. As an engineering student, most of the assignments or projects given required the usage of a laptop to write the assignments and reports and software used for a particular subject to accomplish it.

It is essential to note that the quality of teaching and learning relies on digital access and efficiency. Issues such as limited accessibility to the internet and its speed connection require consideration from the lecturers. Therefore, due to poor internet connection experienced by some of the students, the lecturers had already provided the recording version so that the students can watch later. Furthermore, to overcome the limitation faced by students on their internet speed connection, there are two (2) ways of lectures methods that have been conducted which are synchronize and asynchronous. All the recorded classes and videos made by the lecturers can be downloaded in MT. This ensures that the course thought is assessable for all students at their own pace and time.

In general, the student's perception throughout this online course was excellent. The lion percentage indicated that this course benefited students in electrical engineering knowledge, increased their learning abilities, and developed their confidence level. It shows that the learning flexibility, convenience spaced, and infrastructure availabilities are the major drivers for online education. Likewise, professionalism and etiquette portrayed by the lecturers had a significant impact on the positive response for teaching and learning activities by the students. The online classes conducted had involved frequent two-way communication to keep students focussed via the MT and WhatsApp messenger.

\section{Conclusion}

This paper highlights the perception of ODL practices among electrical engineering students at one of the Malaysian universities during COVID-19 outbreak. The findings of this study indicated that majority of the students displayed positive attitude towards the ODL activities especially in teaching and learning. The frequent two-way interaction developed between students and lecturers had successfully keep the engagement for this course. Ultimately, that reflects to the positive results obtained through the survey that correlate the overall satisfaction of students in the ODL method. Majority of the students indicated that flexibility 
and convenience of the online learning conducted by the lecturers, gave them advantageous in this course. To overcome the technological constraints throughout the ODL session, the asynchronized teaching and learning methods can be deployed. The constraints should also be considered while developing the online course structures for students. For the future study on ODL method effectiveness, we will relate the analyses obtained in this study with students' results-oriented performance. This is important to be documented for further analyzes about the favourable and unfavourable impact of online learning.

\section{References}

Abid, M. I., \& Khan, Z. H. (2018). Towards a holistic approach to improve the retention rate of freshmen in engineering. IEEE International Conference on Teaching, Assessment, and Learning for Engineering (TALE).

Asgari, S., Trajkovic, J., Rahmani, M., Zhang, W., Lo, R. C., \& Sciortino, A. (2021). An observational study of engineering online education during the COVID-19 pandemic. PLOS ONE.

Huggett, C. (2014). The virtual training guidebook: How to design, deliver, and implement live online learning. American Society for Training and Development.

Khan, Z. H., \& Abid, M. I. (2021). Distance learning in engineering education: Challenges and opportunities during COVID-19 pandemic crisis in Pakistan. International Journal of Electrical Engineering Education, 1-20. https://doi.org/10.1177/0020720920988493

Malaysian Qualifications Agency. (2021). Malaysian Qualifications Register (MQR). https://www2.mqa.gov.my/mqr/english/epaparipta.cfm?IDAkrKP=10777

Markom, A. M., Yusof, Y., \& Sadimin, S. (2021). Early Stage of Observation of Open Distance Learning Concept for Introduction to C Programming Course in Malaysia. International Journal of Academic Research in Business and Social Sciences, 11(10), 134-143. https://doi.org/10.6007/ijarbss/v11-i10/11045

Muthuprasad, T., Aiswarya, S., Aditya, K. S., \& Jha, G. K. (2021). Students' perception and preference for online education in India during COVID -19 pandemic. Social Sciences \& Humanities Open, 3(1), 100101. https://doi.org/10.1016/j.ssaho.2020.100101

Sanchez-Gordon, S., \& Luján-Mora, S. (2014). Moocs gone wild. Proceedings of the 8th International Technology, Education and Development Conference (INTED 2014), March, 1449-1458. http://library.iated.org/view/SANCHEZGORDON2014MOO

Selvanathan, M., Hussin, N. A. M., \& Azazi, N. A. N. (2020). Students learning experiences during COVID-19: Work from home period in Malaysian Higher Learning Institutions. Teaching Public Administration. https://doi.org/10.1177/0144739420977900

UNESCO. (2020). COVID-19 Educational disruption and response. https://en.unesco.org/news/covid-19-educational-disruption-and-response 